\title{
Genetics of Type 2 Diabetes: Advances and Future Prospect
}

\section{Sunita Singh*}

Department of Zoology, Mahila Mahavidyalaya, Banaras Hindu University, Varanasi, India

\begin{abstract}
Type 2 diabetes (T2D) is a complex metabolic disorder with an increasing incidence worldwide. The disease is characterized by a combination of impairment in insulin secretion from pancreatic beta cells and insulin resistance of peripheral tissues, especially muscle and liver, resulting from interaction between multiple environmental and genetic factors. Life-style changes and obesity are the major causes for the current epidemic of T2D. The rapidly increasing prevalence of Type 2 diabetes makes it a major healthcare problem worldwide. In the developing nations this poses a serious health care burden. In recent years there has been a swing in the onset to younger age group. To date, Genome-Wide Association Scan (GWAS) studies have identified more than 65 common genetic variants associated with T2D or glucose/insulin levels. The recently discovered genes by GWAS suggest a shift from genes involved in insulin action to those involved in insulin secretion, indicating pivotal role of beta- cell dysfunction in the pathogenesis of T2D. However, in most cases the causal variants are not known. Also, the molecular mechanism of the patho-physiology of the disease is still obscure. Functional studies will be required to identify the mechanisms by which the associated signals impair islet function and increase risk of T2D. Understanding the pathophysiology of T2D will provide new and useful information(s) for prevention of the disease and development of new drugs for the treatment of T2D. Pharmacogenetics is another promising clinical application of the genetic findings for T2D. Also, efforts are being made to understand the genetic basis of differences in disease susceptibility by studying the genetic variations among different populations, an area that is important for the future of medicine.
\end{abstract}

Keywords: Type 2 Diabetes; Genome-wide association scan; Single nucleotide polymorphism; Genetics; Minor allele frequency

\section{Introduction}

The more typical, common and multi-factorial form of Type 2 diabetes results from the interaction between environmental risk factors and predisposing genotype (a combination of genetic variants). (T2D) is characterized by insulin resistance in peripheral tissues like muscle, fat and liver coupled with effects of aging, obesity and reduced exercise [1] and dysregulated insulin secretion by pancreatic betacells. In T2D, the pancreatic beta cells become progressively less able to secrete sufficient insulin to maintain normal carbohydrate and lipid homeostasis [2].

By the year 2030, Type 2 diabetes is expected to affect an estimated 366 million people of world's population [3]. The presence of diabetes mellitus is associated with a range of vascular complications such as myocardial infarction, stroke, heart failure, renal failure, angina, and retinopathy leading to a reduced life expectancy and a reduced quality of life. Increasing morbidity and mortality due to type 2 diabetes makes it a major burden on society worldwide. The potential for modifying risk through adequate treatments and lifestyle alterations make the identification of methods for the early detection of persons at greater risk an important public health challenge.

Several risk factors for type 2 diabetes have been identified, including family history, history of gestational diabetes mellitus, age, sex, obesity, central obesity, low physical activity, smoking, diet, ethnicity, elevated blood pressure, dyslipidemia, stress and different drug treatments. Genetic factors are known to play an important part in the development of $\mathrm{T} 2 \mathrm{D}$, as exemplified by rare monogenic subtypes (MODY) [4-7], the difference in concordance rates between monozygotic and dizygotic twins [8-11] and the high prevalence in particular ethnic groups, and its modification by genetic admixture. Ethnic variation of T2D represents strong evidence for the genetic basis of this disease. The maximum prevalence is recorded in Pima Indians from USA and South Sea Island populations (such as Naurus in Polynesia) where it now reaches 50\% [12,13]. However, the role of genetics in the development of diabetes is poorly understood.

Advances in genotyping technology during the last 7 years have facilitated rapid progress in large-scale genetic studies. The progress in the genetic studies of more common forms of T2D had been slow initially. Recently, a number of genes have been reproducibly associated with T2D risk in multiple genome-wide association studies (GWAS) each making a modest contribution to the overall risk. All identified alleles associated with type 2 diabetes risk are common (minor allele frequency $[\mathrm{MAF}]>5 \%)$ and have a low penetrance $(\mathrm{OR}<1.5)$ in the general population. The role(s) of many of them still needs to be confirmed, and for the majority, the biological and molecular mechanisms are far from being clearly understood.

Although GWAS have greatly improved our understanding of the genetic basis of T2D, most of these studies have been performed in Europeans, and therefore current type 2 diabetes genetic risk models are not likely to be applicable to all populations. The studies involving South Asians are very limited. Inter-population differences in allele frequencies and effect sizes have yielded the discovery of new loci in different populations. There is growing evidence that Asian Indians are at a high risk for $\mathrm{T} 2 \mathrm{D}$ compared to other populations. In recent years, India has become 'diabetes capital' of the world [14]. According to latest estimates, 61 million people in India alone are currently

*Corresponding author: Dr. Sunita Singh, Department of Zoology, Mahila Mahavidyalaya, Banaras Hindu University, Varanasi, India, E-mail: sunitas@bhu.ac.in, sunitasinghvns@gmail.com

Received January 09, 2015; Accepted February 21, 2015; Published February 28, 2015

Citation: Singh S (2015) Genetics of Type 2 Diabetes: Advances and Future Prospect. J Diabetes Metab 6: 518. doi:10.4172/2155-6156.1000518

Copyright: (c) 2015 Singh S. This is an open-access article distributed under the terms of the Creative Commons Attribution License, which permits unrestricted use, distribution, and reproduction in any medium, provided the original author and source are credited. 
afflicted with T2D, and their number is projected to increase to 101 million by 2030 [3]. The relatively unexplored and high-risk Indian population provides an opportunity for genetic dissection of T2D and other metabolic disorders. Also, India represents one of the largest human diversity, consisting of 4635 culturally and anthropologically well-defined populations with little or no gene flow between them [15].

Studies on non-European populations, especially those with unique demographic and cultural histories, are important for identifying population-specific Linkage Disequilibrium (LD) patterns and environmental factors that may modulate disease risk or protection. Given the existence of marked genetic variability among South Asian communities, in addition to diversity in culture, language, caste system, physical appearance, and diet, they do not constitute a single homogeneous community [16]. Although recent GWAS found T2D associated loci largely similar across populations, a few loci still show differential association/protection in populations with different genetic and racial background [17-20]. Therefore, screening populations with a different genetic and racial background or environmental exposures may improve insights about the disease and genetic risk factors.

\section{Genetics of Type 2 Diabetes}

\section{Before GWAS studies}

Only a few of genetic variants had been shown to be clearly associated with T2D before Genome-Wide Association Scan (GWAS) studies. These loci were identified via family-based linkage studies and candidate gene analyses. For the common form of T2D, the discovery of Calpain10 (CAPN10) in a Mexican-American population was the first reported success of linkage-positional cloning strategy for the disease. However, the association could not be reliably replicated in other ethnic groups [21-25]. The genome-wide linkage approach also led to the identification of several other loci associated to T2D, the most prominent being the TCF7L2 (transcription factor 7 like 2) gene on chromosome 10q25.3 [26]. Several T2D associated SNPs have been identified in a region of strong linkage disequilibrium within TCF7L2 (odds ratio for T2D of $\sim 1.4$ fold per allele).

The starting point for the candidate gene approach is the selection of a particular gene that may have potential implications on a biological function or disease. Defects in genes encoding proteins that play a role in pathways involved in insulin control and glucose homeostasis are excellent candidates for type 2 diabetes mellitus. The candidate gene approach led to the identification of a few genes of which two T2D genes are now considered widely replicated: peroxisome proliferatoractivated receptor gamma (PPARG) [27-29], and potassium inwardly rectifying channel, subfamily J, member 11 (KCNJ11) the $\beta$-cell potassium channel (Kir6.2) gene [30-32]. Among all T2D susceptibility genes studied before 2006, only two were found to be convincingly associated, P12A variant in PPARG gene (encoding the target for the thiazolidinedione class of drugs used to treat T2D) by Altshuler et al. [28] and E23K in KCNJ11 (which encodes part of the target for another class of diabetes drug, the sulphonylureas) by Gloyn et al. [30]. But these have only modest effect on disease risk (odds ratio $\sim 1.2$ ).

In 2006, deCODE genetics identified common variation in the TCF7L2 gene to have a substantial effect on T2D susceptibility [33]. TCF7L2 encodes a transcription factor that is active in the Wntsignalling pathway and had no track record as a candidate for T2D. TCF7L2 has been replicated in almost every population examined and, with an OR of about 1.4, represents the strongest T2D susceptibility gene identified so far. The association of TCF7L2 with T2D has been demonstrated in US and Danish subjects [33-35]. The association has also been replicated in diverse subjects of UK [36,37], Amish [38], Finnish [39], French [40], Japanese [41,42], Mexican American [43] origin. Replication of significant associations of ENPPI with risk of obesity and T2D in some [44,45] but not all [46-49] is intriguing. Further, from large-scale candidate pathway studies two more loci were found to be associated with T2D i.e., WFS1 (Wolfram syndrome1) and HNF1- beta (Hepatocyte nuclear factor 1-beta, also known as TCF2). Common variants in Wolfram syndrome1 (WFS1) gene have been found to confer risk of T2D [50]. Also, variants in HNF1-beta (a transcription factor implicated in pancreatic islet development and function) have been found to be associated to T2D [51].

\section{GWAS studies and beyond}

A major breakthrough has been the introduction of the use of genome-wide association scan (GWAS) studies in the year 2007. Substantial advances have been made in the past few years, with genome-wide association scans (GWAS) now allowing unprecedented progress to be made in the understanding of the genetic etiology of several complex diseases, including type 2 diabetes. Initial studies identified T2D-associated variants in loci harboring genes such as solute carrier family 30 (zinc transporter), member 8 (SLC30A8), and two linkage disequilibrium (LD) blocks: insulin degrading enzyme-kinesin factor11-hematopoietically expressed homeobox (IDE-KIF11-HHEX) and exostoses (multiple) 2 (EXT2-ALX) [52,53]. Further, association with CDK5 regulatory subunit associated protein 1-like 1 (CDKAL1), insulin like growth factor $2 \mathrm{mRNA}$-binding protein 2 (IGF2BP2), and cyclin-dependent kinase inhibitor 2A/2B (CDKN2A/2B) was also found [54-57]. The strong association found with variants in TCF7L2, CDKAL1 and CDKN2A/2B to that of T2D implicate wnt-signaling pathway and cell-cycle control in the pathogenesis of T2D [58] Replication of the above six entirely novel T2D susceptibility loci was done in studies involving individuals of both European [59] and Asian [60-63] origin.

Another study using meta-analysis of T2D data found further T2D-associated variants in loci harbouring genes including juxtaposed with another zinc finger gene 1 (JAZF1), cell division cycle 123, calcium/calmodulin-dependent protein kinase 1D (CDC123, CAMK1D), tetraspanin 8, leucine-rich repeat-containing $\mathrm{G}$ proteincoupled receptor 5 (TSPAN8, LGR5), thyroid adenoma associated thyroid adenoma associated (THADA), ADAM metallopeptidase with thrombospondin type 1 motif, 9 (ADAMTS9), and notch gene homolog 2 (NOTCH2) [64,65].

After GWAS in thousands of samples from various populations, enormous amount of data has been generated. The parallel meta-analysis of large association studies was also able to add a few more loci which showed statistical significance with T2D and its traits. The largest metaanalysis for T2D so far was DIAGRAM+ meta-analysis. The combined genome-wide association data from eight cohorts of European descent for $8130 \mathrm{~T} 2 \mathrm{D}$ cases and 38,987 controls was analysed. Overall, 14 signals achieved genome-wide significance, of which, twelve novel associations were identified at BCL11A, ZBED3, KLF14, TP53INP1, CHCHD9, KCNQ1, CENTD2, HMGA2, HNF1A, ZFAND6, PRC1, DUSP9 and two had been previously reported MTNR1B, IRS1 [66]. With the shift from GWAS to GWAS meta-analysis the number of independent loci showing genome-wide significant associations with T2D was raised from 19 to 44 loci in various populations across the world at the end of year 2011. Genome-Wide Association Studies (GWAS) and subsequent meta-analyses have identified $\sim 65$ susceptibility loci for T2D by the end of 2012 that collectively explains only $10 \%$ of the disease risk. 
T2D loci have also been identified through GWAS of related traits. GWAS analysis of fasting glucose concentrations conducted by the metaanalyses of glucose and insulin-related traits consortium (MAGIC) demonstrated association of adenylate cyclase-5 (ADCY5), prosperorelated homeobox-1 (PROX1), glucokinase (GCK), glucokinase regulatory protein (GCKR), and diacylglycerol kinase (DGKB) transmembrane protein-195 (TMEM195) with T2D [67]. Further, GWAS of fasting glucose concentrations have discovered a variant in melatonin receptor 1B (MTNR1B), which was also subsequently found to be associated with T2D [68-70]. Additionally, GWAS for obesity has clearly shown association with fat mass and obesity-associated protein, FTO [71,72]. The advent of GWAS has transformed gene discovery in Type 2 diabetes, with a number of loci identified to date [73-75] These loci have been identified and confirmed through several GWAS analyses (Table 1). Consistent with the complex nature of physiologic defects in T2D, the genetics of the disorder involves a large number of susceptibility genes each with a relatively small effect. However, interaction with other susceptibility loci and/or environmental factors may result in more substantial effects.

Much work is still needed to translate knowledge of these genes into benefits for the patients. There is need to shift the focus from gene discovery to the questions of epigenetic modifications, the transcriptome, protein structure/function and protein interactions,

\begin{tabular}{|c|c|c|c|c|c|c|c|c|}
\hline $\begin{array}{l}\text { Year of } \\
\text { discovery }\end{array}$ & Gene/ SNP & Name of the gene(s) & Allele & $\begin{array}{l}\text { Chromosome } \\
\text { loci }\end{array}$ & Disease Mechanism & Study & OR $(95 \% \mathrm{Cl})$ & Reference \\
\hline 2000 & PPARG/ rs18012824 & $\begin{array}{l}\text { peroxisome proliferative activated } \\
\text { receptor- } y \text { gene }\end{array}$ & C/G & $3 p 25.2$ & Isulin sensitvity & GWAS & $\begin{array}{l}1.14(1.08- \\
1.20)\end{array}$ & [27-29] \\
\hline 2003 & $\begin{array}{l}\text { KCNJ11/ ABCC8/ rs5219/ } \\
\text { rs757110 }\end{array}$ & $\begin{array}{l}\text { potassium inwardly-rectifying } \\
\text { channel, subfamily J, member } 11\end{array}$ & $\begin{array}{l}\mathrm{T} / \mathrm{C} \\
\mathrm{G} / \mathrm{T}\end{array}$ & $11 \mathrm{p} 15.1$ & Beta-cell dysfunction & GWAS & $\begin{array}{l}1.15(1.09- \\
1.21)\end{array}$ & {$[30,31]$} \\
\hline 2006 & TCF7L2/ rs7903146 & Transcription factor 7 like 2 & $\mathrm{~T} / \mathrm{C}$ & 10q25.2 & Beta-cell dysfunction & GWAS & $\begin{array}{l}1.37(1.28- \\
1.47)\end{array}$ & [33-43] \\
\hline 2007 & WFS1/ rs1801214 & Wolfram syndrome 1 & $\mathrm{G} / \mathrm{A}$ & $4 p 16.1$ & Beta-cell dysfunction & GWAS & $\begin{array}{l}1.13(1.07- \\
1.18)\end{array}$ & {$[50]$} \\
\hline 2007 & CDKN2A/2B/ rs10811661 & $\begin{array}{l}\text { cyclin-dependent kinase inhibitor- } \\
2 A / 2 B\end{array}$ & $\mathrm{~T} / \mathrm{C}$ & $9 \mathrm{p} 21.3$ & Beta-cell dysfunction & GWAS & $\begin{array}{l}1.20(1.14- \\
1.25)\end{array}$ & [54-57] \\
\hline 2007 & $\begin{array}{l}\text { CDKAL1/ } \\
\text { rs7754840 }\end{array}$ & $\begin{array}{l}\text { CDK5 regulatory subunit associated } \\
\text { protein 1-like } 1\end{array}$ & C/G & $6 p 22.3$ & Beta-cell dysfunction & GWAS & $\begin{array}{l}1.12(1.08- \\
1.16)\end{array}$ & [54-57] \\
\hline 2007 & SLC30A8/ rs13266634 & solute carrier family 30 ,member 8 & $\mathrm{C} / \mathrm{T}$ & $8 q 24.11$ & $\begin{array}{l}\text { Decreased } \beta \text {-cell } \\
\text { function, }\end{array}$ & GWAS & $\begin{array}{l}1.12(1.07- \\
1.16)\end{array}$ & {$[52,53]$} \\
\hline 2007 & $\begin{array}{l}\text { HHEX/IDE } \\
\text { rs1111875 }\end{array}$ & $\begin{array}{l}\text { hematopoietically expressed } \\
\text { homeobox- insulin-degrading } \\
\text { enzyme }\end{array}$ & $\mathrm{C} / \mathrm{T}$ & $10 q 23.33$ & Beta-cell dysfunction & GWAS & $\begin{array}{l}1.13(1.08- \\
1.17)\end{array}$ & {$[52,53]$} \\
\hline 2007 & HNF1B (TCF2) /rs757210 & $\begin{array}{l}\text { Hepatocyte nuclear factor 1-beta } \\
\text { (Transcription factor } 2 \text { ) }\end{array}$ & A/G & $17 q 12$ & Beta-cell dysfunction & $\begin{array}{l}\text { GWAS } \\
\text { meta- } \\
\text { analysis }\end{array}$ & $\begin{array}{l}1.12(1.07- \\
1.18)\end{array}$ & {$[51]$} \\
\hline 2007 & FTO/ rs8050136 & $\begin{array}{l}\text { Fat mass and obesity-associated } \\
\text { protein }\end{array}$ & $\mathrm{A} / \mathrm{C}$ & $16 q 12.2$ & $\begin{array}{l}\text { obesity, Increased } \\
\text { triglycerides and } \\
\text { cholesterol }\end{array}$ & $\begin{array}{l}\text { GWAS } \\
\text { meta- } \\
\text { analysis }\end{array}$ & $\begin{array}{l}1.15(1.09- \\
1.22)\end{array}$ & {$[71,72]$} \\
\hline 2007 & IGF2BP2/ rs4402960 & $\begin{array}{l}\text { insulin-like growth factor } 2 \text { binding } \\
\text { protein } 2\end{array}$ & $T / G$ & $3 q 28$ & Beta-cell dysfunction & $\begin{array}{l}\text { GWAS } \\
\text { meta- } \\
\text { analysis }\end{array}$ & $\begin{array}{l}1.17(1.10- \\
1.25)\end{array}$ & {$[54-57]$} \\
\hline 2008 & $\begin{array}{l}\text { CDC123/CAMK1D/ } \\
\text { rs12779790 }\end{array}$ & $\begin{array}{l}\text { cell division cycle } 123 \text { homolog (S. } \\
\text { cerevisiae)/ calcium/calmodulin- } \\
\text { dependent protein kinase ID }\end{array}$ & $\mathrm{G} / \mathrm{A}$ & 10p13 & Beta-cell dysfunction & $\begin{array}{l}\text { GWAS } \\
\text { meta- } \\
\text { analysis }\end{array}$ & $\begin{array}{l}1.11(1.07- \\
1.14)\end{array}$ & {$[64,65]$} \\
\hline 2008 & JAZF1/ rs864745 & $\begin{array}{l}\text { juxta-posed with another zinc finger } \\
\text { gene } 1\end{array}$ & $\mathrm{~T} / \mathrm{C}$ & 7p15.1 & Beta-cell dysfunction & $\begin{array}{l}\text { GWAS } \\
\text { meta- } \\
\text { analysis }\end{array}$ & $\begin{array}{l}1.10(1.07- \\
1.13)\end{array}$ & {$[64,65]$} \\
\hline 2008 & TSPAN8/LGR5/ rs7961581 & $\begin{array}{l}\text { tetraspanin8/ Leucine-rich repeat- } \\
\text { containing G protein-coupled } \\
\text { receptor } 5\end{array}$ & $\mathrm{C} / \mathrm{T}$ & $12 q 21.1$ & Beta-cell dysfunction & $\begin{array}{l}\text { GWAS } \\
\text { meta- } \\
\text { analysis }\end{array}$ & $\begin{array}{l}1.09(1.06- \\
1.12)\end{array}$ & {$[64,65]$} \\
\hline 2008 & THADA/ rs7578597 & thyroid adenoma associated & $\mathrm{T} / \mathrm{C}$ & $2 p 21$ & Beta-cell dysfunction & $\begin{array}{l}\text { GWAS } \\
\text { meta- } \\
\text { analysis }\end{array}$ & $\begin{array}{l}1.15(1.10- \\
1.20)\end{array}$ & {$[64,65]$} \\
\hline 2008 & ADAMTS9/ rs4607103 & $\begin{array}{l}\text { ADAM metallopeptidase with } \\
\text { thrombospondin type } 1 \text { motif, } 9\end{array}$ & $\mathrm{C} / \mathrm{T}$ & $3 p 14.1$ & $\begin{array}{l}\text { Decreased insulin } \\
\text { sensitivity }\end{array}$ & $\begin{array}{l}\text { GWAS } \\
\text { meta- } \\
\text { analysis }\end{array}$ & $\begin{array}{l}1.09(1.06- \\
1.12)\end{array}$ & {$[64,65]$} \\
\hline 2008 & NOTCH2/ rs10923931 & $\begin{array}{l}\text { Neurogenic locus notch homolog } \\
\text { protein } 2\end{array}$ & T/G & $1 \mathrm{p} 11.2$ & $\begin{array}{l}\text { Unknown (Membrane } \\
\text { receptor) }\end{array}$ & $\begin{array}{l}\text { GWAS } \\
\text { meta- } \\
\text { analysis }\end{array}$ & $\begin{array}{l}1.13(1.08- \\
1.17)\end{array}$ & {$[64,65]$} \\
\hline 2008 & $\begin{array}{l}\text { KCNQ1/ rs2237892 / } \\
\text { rs231362 }\end{array}$ & $\begin{array}{l}\text { Potassium voltage-gated channel } \\
\text { subfamily KQT member } 1\end{array}$ & $\begin{array}{l}C / T \\
G / A\end{array}$ & $11 \mathrm{p} 15.5$ & Beta-cell dysfunction & $\begin{array}{l}\text { GWAS } \\
\text { meta- } \\
\text { analysis }\end{array}$ & $\begin{array}{l}1.4(1.34- \\
1.47) \\
1.08(1.06- \\
1.10)\end{array}$ & {$[66]$} \\
\hline 2009 & IRS1/ rs2943641 & Insulin receptor substrate 1 & $\mathrm{C} / \mathrm{T}$ & $2 q 36.3$ & $\begin{array}{l}\text { Increased insulin } \\
\text { resistance }\end{array}$ & GWAS & $\begin{array}{l}1.19(1.13- \\
1.25)\end{array}$ & [66] \\
\hline 2010 & $\begin{array}{l}\text { DGKB-TMEM195/ } \\
\text { rs2191349 }\end{array}$ & $\begin{array}{l}\text { Diacylglycerol kinase beta- } \\
\text { Alkylglycerol monooxygenase }\end{array}$ & $T / G$ & 7p21.2 & $\begin{array}{l}\text { Decreased } \beta \text {-cell } \\
\text { function, increased } \\
\text { fasting glucose }\end{array}$ & $\begin{array}{l}\text { GWAS } \\
\text { meta- } \\
\text { analysis }\end{array}$ & $\begin{array}{l}1.06(1.04- \\
1.08)\end{array}$ & [67] \\
\hline
\end{tabular}


Page 4 of 8

\begin{tabular}{|c|c|c|c|c|c|c|c|c|}
\hline 2010 & GCK/ rs4607517 & glucokinase & A/G & 7p13 & Insulin sensitivity & $\begin{array}{l}\text { GWAS } \\
\text { meta- } \\
\text { analysis }\end{array}$ & $\begin{array}{l}1.07(1.05- \\
1.10)\end{array}$ & [67] \\
\hline 2010 & GCKR/ rs780094 & Glucokinase regulatory protein & $\mathrm{C} / \mathrm{T}$ & $2 \mathrm{p} 23.3$ & $\begin{array}{l}\text { Increased insulin } \\
\text { resistance }\end{array}$ & $\begin{array}{l}\text { GWAS } \\
\text { meta- } \\
\text { analysis }\end{array}$ & $\begin{array}{l}1.06(1.04- \\
1.08)\end{array}$ & [67] \\
\hline 2010 & PROX1/ rs340874 & prospero homeobox 1 & $\mathrm{C} / \mathrm{T}$ & $1 \mathrm{q} 32.3$ & $\begin{array}{l}\text { Decreased } \beta \text {-cell } \\
\text { function, increased } \\
\text { fasting glucose }\end{array}$ & $\begin{array}{l}\text { GWAS } \\
\text { meta- } \\
\text { analysis }\end{array}$ & $\begin{array}{l}1.07(1.05- \\
1.09)\end{array}$ & [67] \\
\hline 2010 & ADCYS/ rs11708067 & Adenylate cyclase 5 & A/G & $3 q 21.1$ & $\begin{array}{l}\text { Decreased insulin } \\
\text { sensitivity }\end{array}$ & $\begin{array}{l}\text { GWAS } \\
\text { meta- } \\
\text { analysis }\end{array}$ & $\begin{array}{l}1.12(1.09- \\
1.15)\end{array}$ & [67] \\
\hline 2010 & DUSP9/ rs5945326 & dual specificity phosphatase 9 & G/A & Xq28 & Phosphatase & $\begin{array}{l}\text { GWAS } \\
\text { meta- } \\
\text { analysis }\end{array}$ & $\begin{array}{l}1.27(1.18- \\
1.37)\end{array}$ & [66] \\
\hline 2010 & BCL11A/ rs243021 & $\begin{array}{l}\text { B-cell CLL/lymphoma 11A (zinc } \\
\text { finger protein) (BCL11A), transcript } \\
\text { variant } 1\end{array}$ & A/G & 2p16.1 & Beta-cell dysfunction & $\begin{array}{l}\text { GWAS } \\
\text { meta- } \\
\text { analysis }\end{array}$ & $\begin{array}{l}1.08(1.06- \\
1.10)\end{array}$ & [66] \\
\hline 2010 & ZBED3/ rs4457053 & $\begin{array}{l}\text { Zinc finger BED domain-containing } \\
\text { protein } 3\end{array}$ & G/A & $5 q 13.3$ & Beta-cell dysfunction & $\begin{array}{l}\text { GWAS } \\
\text { meta- } \\
\text { analysis }\end{array}$ & $\begin{array}{l}1.08(1.06- \\
1.11)\end{array}$ & [66] \\
\hline 2010 & KLF14/ rs972283 & Krueppel-like factor 14 & G/A & 7q32.3 & Insulin action & $\begin{array}{l}\text { GWAS } \\
\text { meta- } \\
\text { analysis }\end{array}$ & $\begin{array}{l}1.07(1.05- \\
1.10)\end{array}$ & [66] \\
\hline 2010 & TP53INP1/ rs896854 & $\begin{array}{l}\text { Tumor protein p53-inducible nuclear } \\
\text { protein } 1\end{array}$ & $\mathrm{~T} / \mathrm{C}$ & $8 \mathrm{q} 22.1$ & Unknown & $\begin{array}{l}\text { GWAS } \\
\text { meta- } \\
\text { analysis }\end{array}$ & $\begin{array}{l}1.06(1.04- \\
1.09)\end{array}$ & [66] \\
\hline 2010 & CHCHD9/ rs13292136 & $\begin{array}{l}\text { Putative coiled-coil-helix-coiled- } \\
\text { coil-helix domain-containing protein } \\
\text { CHCHD2P9 }\end{array}$ & $\mathrm{C} / \mathrm{T}$ & 9q21.31 & Unknown & $\begin{array}{l}\text { GWAS } \\
\text { meta- } \\
\text { analysis }\end{array}$ & $\begin{array}{l}1.11(1.07- \\
1.15)\end{array}$ & [66] \\
\hline 2010 & $\begin{array}{l}\text { CENTD2/ ARAP1/ } \\
\text { rs1552224 }\end{array}$ & $\begin{array}{l}\text { ANK repeat and PH domain- } \\
\text { containing protein } 1\end{array}$ & $\mathrm{~A} / \mathrm{C}$ & $11 \mathrm{q} 13.4$ & Beta-cell dysfunction & $\begin{array}{l}\text { GWAS } \\
\text { meta- } \\
\text { analysis }\end{array}$ & $\begin{array}{l}1.14(1.11- \\
1.17)\end{array}$ & [66] \\
\hline 2010 & HMGA2/ rs1531343 & High mobility group protein $\mathrm{HMGI-C}$ & C/G & $12 q 14.3$ & $\begin{array}{l}\text { Transcriptional } \\
\text { regulator }\end{array}$ & $\begin{array}{l}\text { GWAS } \\
\text { meta- } \\
\text { analysis }\end{array}$ & $\begin{array}{l}1.10(1.07- \\
1.14)\end{array}$ & [66] \\
\hline 2010 & HNF1A/ rs7957197 & Hepatocyte nuclear factor 1-alpha & T/A & 12q24.31 & $\begin{array}{l}\text { Pancreatic and } \\
\text { liver transcriptional } \\
\text { regulator }\end{array}$ & $\begin{array}{l}\text { GWAS } \\
\text { meta- } \\
\text { analysis }\end{array}$ & $\begin{array}{l}1.07(1.05- \\
1.10)\end{array}$ & [66] \\
\hline 2010 & ZFAND6/ rs11634397 & AN1-type zinc finger protein 6 & $\mathrm{G} / \mathrm{A}$ & $15 q 25.1$ & Beta-cell dysfunction & $\begin{array}{l}\text { GWAS } \\
\text { meta- } \\
\text { analysis }\end{array}$ & $\begin{array}{l}1.06(1.04- \\
1.08)\end{array}$ & [66] \\
\hline 2010 & PRC1/ rs8042680 & Protein regulator of cytokinesis 1 & $\mathrm{~A} / \mathrm{C}$ & $15 q 26.1$ & $\begin{array}{l}\text { Unknown ( Cytokinesis } \\
\text { regulator) }\end{array}$ & $\begin{array}{l}\text { GWAS } \\
\text { meta- } \\
\text { analysis }\end{array}$ & $\begin{array}{l}1.07(1.05- \\
1.09)\end{array}$ & [66] \\
\hline 2010 & MTNR1B/ rs10830963 & Melatonin receptor type 1B & G/C & $11 q 14.3$ & $\begin{array}{l}\text { Decreased } \beta \text {-cell } \\
\text { function, , increased } \\
\text { fasting glucose }\end{array}$ & $\begin{array}{l}\text { GWAS } \\
\text { meta- } \\
\text { analysis }\end{array}$ & $\begin{array}{l}1.09(1.06- \\
1.12)\end{array}$ & {$[66,68-70]$} \\
\hline
\end{tabular}

Table 1: T2D loci reaching statistical significance identified by GWAS and GWAS meta-analysis.

developmental and physiological pathways and systems biology as routes to the application of this knowledge for direct patient benefits. Different bioinformatic and proteomic analysis have found shared molecular pathogenesis with a wide variety of other disorders e.g. neurological disorders [76-78]. Some of the genes found to be associated with T2D also appear to be key players in cancer pathogenesis $[79,80]$. Thus, we find that high throughput methods like GWAS, bioinformatic and system biology approaches help to generate novel hypotheses and illuminate new aspects of biology.

\section{Current Status in Indian Population}

Several lines of evidence from population based studies suggest that Indians are apparently genetically more prone to diabetes and insulin resistance. Also, Asian Indians are more susceptible to developing truncal obesity, which might account for their tendency to insulin resistance referred to as "Asian Indian phenotype" [81-85].

Among all the association studies with T2D in Indian populations [86], TCF7L2 has been shown to be most promising in south Indian
[87] and western Indian [88,89] populations, where intronic SNP (rs12255372, rs7903146) show association with T2D. The rs1055080 and (TCC)n repeat polymorphisms of FOXA2 independently influence the risk of type 2 diabetes and affect metabolic traits, with opposing effects, in North India [90]. They have identified common and rare variants of FOXA2 and analyzed for their genetic association to T2D. Chauhan et al. [89] have replicated association of eight well established genetic variants with $\mathrm{T} 2 \mathrm{D}$ in north-western Indian populations showing higher effect size compared to the Europeans. We have also shown higher effect size compared to European populations of two of the well established genetic variants in eastern Uttar Pradesh population of India [91].

First GWAS on Indian polulation for T2D in 12,535 Indians, revealed a new type 2 diabetes associated locus at 2q21, with the lead signal being rs6723108 (odds ratio 1.31; $\mathrm{P}=3.3 \times 10^{-9}$ ). Imputation analysis refined the signal to rs998451 (odds ratio $1.56 ; \mathrm{P}=6.3 \times 10^{-12}$ ) within TMEM163 that encodes a probable vesicular transporter in nerve terminals. TMEM163 variants also showed association with 
decreased fasting plasma insulin and homeostatic model assessment of insulin resistance, indicating a plausible effect through impaired insulin secretion. Forty-nine of 56 previously reported signals showed consistency in direction with similar effect sizes in Indians and other previous studies, and 25 of them were also found to be associated $(\mathrm{P}<0.05)$ to T2D. Known loci and the newly identified 2q21 locus altogether explained 7.65\% variance in the risk of T2D in Indians [19]. The study suggests that common susceptibility variants for T2D are largely same across populations, and also reveals a population specific locus providing further insights into genetic architecture and etiology of T2D.

Recently, replication of Type 2 Diabetes candidate genes variations in three geographically unrelated Indian population groups has been conducted. The study suggests TCF7L2, HHEX, IDE, ENPP1 and FTO as commonly associated T2D susceptibility genes in the three Indian populations. Interaction analyses have shown an increased effect in associations suggesting the importance of gene and pathway based interaction between multiple functionally important genes [92]. Combined meta-analysis in Sikh population ( $\mathrm{n}=7,329 ; 3,354$ case subjects) from India revealed a novel locus associated with T2D at 13q12 represented by a directly genotyped intronic SNP (rs9552911, $\left.\mathrm{P}=1.82 \times 10^{-8}\right)$ in the SGCG gene. This finding provides new evidence supporting population-specific signal in relation to T2D. This may provide additional insights into T2D pathogenesis [20].

\section{Conclusion}

Type 2 Diabetes mellitus is rapidly becoming substantial health issue and therefore a burden on current society. Evidence from several studies indicates that diabetes is a heterogeneous disease. The major issue to address in diabetes biology is to identify the genetic changes in the disease and their occurrence in different populations. Uncovering these genetic changes in diabetes are important in several ways, specifically, (a) defining the mechanistic and functional role of specific genetic alterations; (b) developing potential biomarkers to differentiate high risk from low risk; and (c) testing and designing genetic based strategies against a specific genetic alteration.

Significant advances have been made in recent years in relation to the pathogenesis of T2D. This has significantly improved our knowledge of one of the most serious global health threats, allowing identification of genes and pathways involved in the development and progression of the disease. However, due to the multifactorial nature of the disease, how the identified genes and pathways impact on T2D still remain largely unknown. Understanding the pathogenesis of T2D is necessary to enable the identification of prognostic and predictive biomarkers, as well as new therapeutic targets, which in turn should lead to improved outcomes in affected patients.

A number of studies have demonstrated that common variants with low penetrance have little predictive power [93-98]. In contrast, it has been proposed that accumulation of rare variants with a mildly deleterious effect may substantially increase the relative risk at the individual level. Indeed, with the next generation of sequencing technologies, rare variants may be identified. Such results together with the known common susceptibility variants may increase the discriminative value of genetic risk factors and push the limit towards a threshold acceptable for clinical utility.

\section{Future Perspective}

Since 2007, genome-wide association studies (GWAS) have identified more than 65 genetic variants that increase the risk of type 2 diabetes by $10-30 \%[99,100]$. However, the challenge is to investigate the functional consequences of these variants as most of these variants are noncoding variants. Many of the variants identified to date regulate insulin secretion and not insulin action in insulin-sensitive tissues indicating role of beta-cell (dys)function in the pathogenesis of T2D [17-18,57,59,101-103].

Identification of a large number of novel genetic variants increasing susceptibility to type 2 diabetes and related traits opened up opportunity, to translate this genetic information to the clinical practice and possibly improve risk prediction. Genetic testing for the prediction of type 2 diabetes in high risk individuals is currently of little value in clinical practice [104]. The investigations in this direction face limitations in genetic modelling. These limitations include (a) effect size of the genetic loci are usually small, (b) the ability of genetic tests to discriminate are low, (c) the added value of genetic information is smaller compared to the clinical risk factors, (d) clinical relevance of some of the genetic variants in disease prediction is questionable, and (e) appropriate model systems for studying gene-gene and geneenvironment interactions in the risk prediction is still lacking. Use of new high-throughput sequencing techniques may be useful in identification of low-frequency and rare variants with large effect size. Investigations in non-European ancestry populations will be more useful in identification of new variants critical in T2D prediction, since for genetic risk prediction and for targeted disease therapy how much genetic risk loci can be translated between different ethnicities is vital. Also, epigenetic and structural variation studies can identify new variants that may be important in $\mathrm{T} 2 \mathrm{D}$ disease prediction. There is urgent need of developing new statistical methods that can be applied in gene-gene and gene-environment interaction studies in large populations [98].

In a systematic review by Maruthur et al. [105], based on 34 articles on the pharmacogenetics of diabetes medications, evidence of biologically plausible pharmacogenetic interactions for metformin, sulfonylureas, repaglinide, pioglitazone, rosiglitazone, and acarbose, were identified with several studies reporting statistically significant interactions between genetic variants and medications for glycemic outcomes. These results require confirmation in future studies to determine if an individual's genetic information can be used to individualize the choice of prediabetes and diabetes pharmacologic management.

\section{Acknowledgement}

Prof. Gopeshwar Narayan, Department of Molecular and Human Genetics Banaras Hindu University is thankfully acknowledged for proof-reading the manuscript.

\section{References}

1. Saltiel AR, Kahn CR (2001) Insulin signalling and the regulation of glucose and lipid metabolism. Nature 414: 799-806.

2. Bell GI, Polonsky KS (2001) Diabetes mellitus and genetically programmed defects in beta-cell function. Nature 414: 788-791.

3. International Diabetes Federation (2011) Diabetes Atlas. Belgium, International Diabetes Federation, 2011

4. Waterfield T, Gloyn AL (2008) Monogenic ß-cell dysfunction in children: clinical phenotypes, genetic etiology and mutational pathways. Pediatr Health 2: 517 532.

5. Fajans SS, Bell GI, Polonsky KS (2001) Molecular mechanisms and clinica pathophysiology of maturity-onset diabetes of the young. N Engl J Med 345: 971-980.

6. Ellard S, Bellanné-Chantelot C, Hattersley AT (2008) European Molecula Genetics Quality Network (EMQN) MODY group. Best practice guidelines 
for the molecular genetic diagnosis of maturity-onset diabetes of the young. Diabetologia 51: 546-553.

7. McCarthy MI, Hattersley AT (2008) Learning from molecular genetics: nove insights arising from the definition of genes for monogenic and type 2 diabetes. Diabetes 57: 2889-2898.

8. Vaag A, Poulsen $P(2007)$ Twins in metabolic and diabetes research: what do they tell us? Curr Opin Clin Nutr Metab Care 10: 591-596.

9. Almgren P, Lehtovirta M, Isomaa B, Sarelin L, Taskinen MR, et al. (2011) Heritability and familiality of type 2 diabetes and related quantitative traits in the Botnia Study. Diabetologia 54: 2811-2819.

10. Barnett AH, Eff C, Leslie RD, Pyke DA (1981) Diabetes in identical twins. A study of 200 pairs. Diabetologia 20: 87-93.

11. Kaprio J, Tuomilehto J, Koskenvuo M, Romanov K, Reunanen A, et al. (1992) Concordance for type 1 (insulin-dependent) and type 2 (non-insulin-dependent) diabetes mellitus in a population-based cohort of twins in Finland. Diabetologia 35: 1060-1067.

12. Shaw JE, Sicree RA, Zimmet PZ (2010) Global estimates of the prevalence of diabetes for 2010 and 2030. Diabetes Res Clin Pract 87: 4-14.

13. Knowler WC, Pettitt DJ, Saad MF, Bennett PH (1990) Diabetes mellitus in the Pima Indians: incidence, risk factors and pathogenesis. Diabetes Metab Rev 6: 1-27.

14. Wild S, Roglic G, Green A, Sicree R, King H (2004) Global prevalence of diabetes: estimates for the year 2000 and projections for 2030. Diabetes Care 27: 1047-1053

15. Indian Genome Variation Consortium1 (2008) Genetic landscape of the people of India: a canvas for disease gene exploration. J Genet 87: 3-20.

16. Kivisild T, Bamshad MJ, Kaldma K, Metspalu M, Metspalu E, et al. (1999) Deep common ancestry of indian and western-Eurasian mitochondrial DNA lineages. Curr Biol 9: 1331-1334

17. Unoki H, Takahashi A, Kawaguchi T, Hara K, Horikoshi M, et al. (2008) SNPs in KCNQ1 are associated with susceptibility to type 2 diabetes in East Asian and European populations. Nat Genet 40: 1098-1102.

18. Yasuda K, Miyake K, Horikawa Y, Hara K, Osawa H, et al. (2008) Variants in KCNQ1 are associated with susceptibility to type 2 diabetes mellitus. Nat Genet 40: 1092-1097.

19. Tabassum R, Chauhan G, Dwivedi OP, Mahajan A, Jaiswal A, et al. (2013) Genome-wide association study for type 2 diabetes in Indians identifies a new susceptibility locus at 2q21. Diabetes 62: 977-986.

20. Saxena R, Saleheen D, Been LF, Garavito ML, Braun T, et al. (2013) GenomeWide Association Study Identifies a Novel Locus Contributing to Type 2 Diabetes Susceptibility in Sikhs of Punjabi Origin From India. Diabetes 62 : 1746-1755.

21. Horikawa Y, Oda N, Cox NJ, Li X, Orho-Melander M, et al. (2000) Genetic variation in the gene encoding calpain-10 is associated with type 2 diabetes mellitus. Nat Genet 26: 163-175.

22. Weedon MN, Schwarz PE, Horikawa Y, Iwasaki N, Illig T, et al. (2003) Metaanalysis and a large association study confirm a role for calpain-10 variation in type 2 diabetes susceptibility. Am J Hum Genet 73: 1208-1212.

23. Song Y, Niu T, Manson JE, Kwiatkowski DJ, Liu S (2004) Are variants in the CAPN10 gene related to risk of type 2 diabetes? A quantitative assessment of population and family-based association studies. Am J Hum Genet 74: 208222.

24. Cassell PG, Jackson AE, North BV, Evans JC, Synder D, et al. (2002) Haplotype combinations of calpain-10 gene polymorphisms associate with increased risk of impaired glucose tolerance and type 2 diabetes. Diabetes 51: 1622-1628.

25. Tsuchiya T, Schwarz PE, Bosque-Plata LD, Geoffrey Hayes M, Dina C, et al (2006) Association of the calpain-10 gene with type 2 diabetes in Europeans: results of pooled and meta-analyses. Mol Genet Metab 89: 174-184.

26. Reynisdottir I, Thorleifsson G, Benediktsson R, Sigurdsson G, Emilsson V, et al. (2003) Localization of a susceptibility gene for type 2 diabetes to chromosome 5q34-q35.2. Am J Hum Genet 73: 323-335.

27. Barroso I, Gurnell M, Crowley VE, Agostini M, Schwabe JW, et al. (1999) Dominant negative mutations in human PPARgamma associated with severe insulin resistance, diabetes mellitus and hypertension. Nature 402: 880-883.
28. Altshuler $D$, Hirschhorn JN, Klannemark $M$, Lindgren $C M$, Vohl MC, et al. (2000) The common PPARgamma Pro12Ala polymorphism is associated with decreased risk of type 2 diabetes. Nat Genet 26: 76-80.

29. Agostini M, Gurnell M, Savage DB (2004) Tyrosine agonists reverse the molecular defects associated with dominant-negative mutations in human peroxisome proliferator-activated receptor gamma. Endocrinology 145: $1527-$ 1538.

30. Gloyn AL, Weedon MN, Owen KR, Turner MJ, Knight BA, et al. (2003) Largescale association studies of variants in genes encoding the pancreatic betacell K-ATP channel subunits Kir6.2 (KCNJ11) and SUR1 (ABCC8) confirm that the KCNJ11 E23K variant is associated with Type 2 diabetes. Diabetes 52 568-572.

31. Florez JC, Burtt N, de Bakker PI, Almgren P, Tuomi T, et al. (2004) Haplotype structure and genotype phenotype correlations of the sulfonylurea receptor and the islet ATP-sensitive potassium channel gene region. Diabetes 53: 13601368.

32. Schwanstecher C, Meyer U, Schwanstecher M (2002) K(IR)6.2 polymorphism predisposes to type 2 diabetes by inducing overactivity of pancreatic beta-cell ATP-sensitive $\mathrm{K}(+)$ channels. Diabetes 51: 875-879.

33. Grant SF, Thorleifsson G, Reynisdottir I, Benediktsson R, Manolescu A, et al (2006) Variant of transcription factor 7-like 2 (TCF7L2) gene confers risk of type 2 diabetes. Nat Genet 38: 320-323.

34. Zhang C, Qi L, Hunter DJ, Meigs JB, Manson JE, et al. (2006) Variant of transcription factor 7-like 2 (TCF7L2) gene and the risk of type 2 diabetes in large cohorts of U.S. women and men. Diabetes 55: 2645-2648.

35. Saxena R, Gianniny L, Burtt NP, Lyssenko V, Giuducci C, et al. (2006) Common single nucleotide polymorphisms in TCF7L2 are reproducibly associated with type 2 diabetes and reduce the insulin response to glucose in nondiabetic individuals. Diabetes 55: 2890-2895.

36. Groves CJ, Zeggini E, Minton J, Frayling TM, Weedon MN, et al. (2006 Association analysis of 6,736 U.K. subjects provides replication and confirms TCF7L2 as a type 2 diabetes susceptibility gene with a substantial effect on individual risk. Diabetes 55: 2640-2644.

37. Florez JC, Jablonski KA, Bayley N, Pollin TI, de Bakker PI, et al. (2006) TCF7L2 polymorphisms and progression to diabetes in the Diabetes Prevention Program. N Engl J Med 355: 241-250.

38. Damcott CM, Pollin TI, Reinhart LJ, Ott SH, Shen H, et al. (2006) Polymorphisms in the transcription factor 7-like 2 (TCF7L2) gene are associated with type 2 diabetes in the Amish: replication and evidence for a role in both insulin secretion and insulin resistence. Diabetes 55: 2654-2659.

39. Scott LJ, Bonnycastle LL, Willer CJ, Sprau AG, Jackson AU, et al. (2006) Association of transcription factor 7-like 2 (TCF7L2) variants with type 2 diabetes in a Finnish sample. Diabetes 55: 2649-2653.

40. Cauchi S, Meyre D, Dina C, Choquet H, Samson C, et al. (2006) Transcription factor TCF7L2 genetic study in the French population: Expression in human \{beta\}-cells and adipose tissue and strong association with type 2 diabetes. Diabetes 55: 2903-2908

41. Hayashi T, Iwamoto Y, Kaku K, Hirose H, Maeda S (2007) Replication study for the association of TCF7L2 with susceptibility to type 2 diabetes in a Japanese population. Diabetologia 50: 980-984

42. Horikoshi M, Hara K, Ito C, Nagai R, Froguel P, et al. (2007) A genetic variation of the transcription factor 7 -like 2 gene is associated with risk of type 2 diabetes in the Japanese population. Diabetologia 50: 747-751.

43. Lehman DM, Hunt KJ, Leach RJ, Hamlington J, Arya R, et al. (2007) Haplotypes of transcription factor 7-like 2 (TCF7L2) genes and its upstream region are associated with type 2 diabetes and age of onset in Mexican Americans. Diabetes 56: 389-393.

44. Bottcher Y, Korner A, Reinehr T, Enigk B, Kiess W, et al (2006) ENPP1 variants and haplotypes predispose to early onset obesity and impaired glucose and insulin metabolism in German obese children. J Clin Endocrino Metab 91: 4948-4952.

45. Bochenski J, Placha G, Wanic K, Malecki M, Sieradzki J, et al. (2006) New polymorphism of ENPP1 (PC-1) is associated with increased risk of type 2 diabetes among obese individuals. Diabetes 55: 2626-2630.

46. Weedon MN, Shields B, Hitman G, Walker M, McCarthy MI, et al. (2006) No evidence of association of ENPP1 variants with type 2 diabetes or obesity in a study of 8,089 U.K. Caucasians. Diabetes 55: 3175-3179. 
47. Grarup N, Urhammer SA, Ek J, Albrechtsen A, Glumer C, et al. (2006) Studies of the relationship between the ENPP1 K121Q polymorphism and type 2 diabetes, insulin resistance and obesity in 7333 Danish white subjects. Diabetologia 49: 2097-2104.

48. Keshavarz P, Inoue H, Sakamoto $Y$, Kunika K, Tanahashi T, et al. (2006) No evidence for association of the ENPP1 (PC-1) K121Q variant with risk of type 2 diabetes in a Japanese population. J Hum Genet 51: 559-566.

49. Lyon HN, Florez JC, Bersaglieri T, Saxena R, Winckler W, et al. (2006) Common variants in the ENPP1 gene are not reproducibly associated with diabetes or obesity. Diabetes 55: 3180-3184

50. Sandhu MS, Weedon MN, Fawcett KA, Wasson J, Debenham SL, et al. (2007) Common variants in WFS1 confer risk of type 2 diabetes. Nat Genet 39: 951 953.

51. Winckler W, Graham RR, de Bakker PI, Sun M, Almgren P, et al. (2005) Association testing of variants in the hepatocyte nuclear factor 4alpha gene with risk of type 2 diabetes in 7,883 people. Diabetes 54: 886-892.

52. Sladek R, Rocheleau G, Rung J, Dina C, Shen L, et al. (2007) A genome-wide association study identifies novel risk loci for type 2 diabetes. Nature 445: 881885

53. Schulze MB, Al-Hasani H, Boeing H, Fisher E, Doring F, et al. (2007) Variation in the HHEX- IDE gene region predisposes to type 2 diabetes in the prospective, population based EPIC- Potsdam cohort. Diabetologia 50: 2405- 2407

54. Zeggini E, Weedon MN, Lindgren CM, Frayling TM, Elliott KS, et al. (2007) Replication of genome-wide association signals in UK samples reveals risk loci for type 2 diabetes. Science 316: 1336-1341.

55. Saxena R, Voight BF, Lyssenko V, Burtt NP, de Bakker PI, et al. (2007) Genome-wide association analysis identifies loci for type 2 diabetes and triglyceride levels. Science 316: 1331-1336.

56. Scott LJ, Mohlke KL, Bonnycastle LL, Willer CJ, Li Y, et al. (2007) A genomewide association study of type 2 diabetes in Finns detects multiple susceptibility variants. Science 316: 1341-1345.

57. Steinthorsdottir V, Thorleifsson G, Reynisdottir I, Benediktsson R, Jonsdottir T, et al. (2007) A variant in CDKAL1 influences insulin response and risk of type 2 diabetes. Nat Genet 39: 770-775.

58. Frayling TM, McCarthy MI (2007) Genetic studies of diabetes following the advent of the genome-wide association study: where do we go from here? Diabetologia 50: 2229-2233.

59. Grarup N, Rose CS, Andersson EA, Andersen G, Nielsen AL, et al. (2007) Studies of association of variants near the HHEX, CDKN2A/B and IGF2BP2 genes with type 2 diabetes and impaired insulin release in 10,705 Danish subjects validation and extension of genome-wide association studies. Diabetes 56: 3105-3111.

60. Omori S, Tanaka Y, Takahashi A, Hirose H, Kashiwagi A, et al. (2008) Association of CDKAL, IGF2BP2, CDKN2A/B, HHEX, SLC30A8, and KCNJ11 with susceptibility to type 2 diabetes in a Japanese population. Diabetes 57 : 791-795

61. Wu Y, Li H, Loos RJ, Yu Z, Ye X, et al. (2008) Common variants in CDKAL, CDKN2A/B,IGF2BP2, SLC30A8 and HHEX/IDE genes are associated with type 2 diabetes and impaired fasting glucose in a Chinese Han population. Diabetes 57: 2834-2842.

62. Ng MC, Park KS, Oh B, Tam CH, Cho YM, et al. (2008) Implication of genetic variants near TCF7L2, SLC30A8, HHEX, CDKAL, CDKN2A/B, IGF2BP2, and FTO in type 2 diabetes and obesity in 6,719 Asians. Diabetes 57: 2226-2233.

63. Sanghera DK, Ortega L, Han S, Singh J, Ralhan SK, et al. (2008) Impact of nine common type 2 diabetes risk polymorphisms in Asian Indian Sikhs: PPARG2 (Pro12Ala), IGF2BP2,TCF7L2 and FTO variants confer a significant risk. BMC Med Genet 9: 59

64. Zeggini E ,Scott LJ, Saxena R, Hu T, Voight BF, et al. (2008) Meta-analysis of genome-wide association data and large-scale replication identifies additional susceptibility loci for type 2 diabetes. Nat Genet 40: 638-645.

65. Omori S, Tanaka Y, Horikoshi M, Takahashi A, Hara K, et al., (2009) Replication study for the association of new meta analysis derived risk loci with susceptibility to type 2 diabetes in 6,244 Japanese individuals. Diabetologia 52: $1554-1560$

66. Voight BF, Scott LJ, Steinthorsdottir V, Morris AP, Dina C, et al. (2010) Twelve type 2 diabetes susceptibility loci identified through large-scale association analysis. Nat Genet 42: 579-589.

67. Dupuis J, Langenberg C, Prokopenko I, Saxena R, Soranzo N, et al. (2010) New genetic loci implicated in fasting glucose homeostasis and their impact on type 2 diabetes risk. Nat Genet 42: 105-116

68. Bouatia-Naji N, Bonnefond A, Cavalcanti-Proenca C, Spars $\varnothing$ T, Holmkvist J, et al. (2009) A variant near MTNR1B is associated with increased fasting plasma glucose levels and type 2 diabetes risk. Nat Genet 41: 89-94.

69. Lyssenko V, Nagorny CL, Erdos MR, Wierup N, Jonsson A, et al. (2009) Common variant in MTNR1B associated with increased risk of type 2 diabetes and impaired early insulin secretion. Nat Genet 41: 82-88.

70. Prokopenko I, Langenberg C, Florez JC, Saxena R, Soranzo N, et al. (2009) Variants in MTNR1B influence fasting glucose levels. Nat Genet 41: 77-81.

71. Frayling TM, Timpson NJ, Weedon MN, Zeggini E, Freathy RM, et al. (2007) A common variant in the FTO gene is associated with body mass index and predisposes to childhood and adult obesity. Science 316: 889-894.

72. Burton PR, Clayton DG, Cardon LR, Craddock N, Deloukas P, et al. (2007) Genome-wide association study of 14,000 cases of seven common diseases and 3,000 shared controls. Nature 447: 661-678.

73. Imamura M, Maeda S (2011) Genetics of type 2 diabetes: the GWAS era and future perspectives [Review]. Endocr J 58: 723-739.

74. Guja C, Gagniuc $P$, lonescu-Tîrgoviste $C$ (2012) Genetic factors involved in the pathogenesis of type 2 diabetes. Proc Rom Acad, Series B 1: 44-61.

75. Basile KJ, Johnson ME, Xia Q, Grant SF2 (2014) Genetic susceptibility to type 2 diabetes and obesity: follow-up of findings from genome-wide association studies. Int J Endocrinol 2014: 769671.

76. Mirza Z, Ali A, Ashraf GM, Kamal MA, Abuzenadah AM, et al. (2014) Proteomics approaches to understand linkage between Alzheimer's disease and type 2 diabetes mellitus. CNS Neurol Disord Drug Targets 13: 213-225.

77. Ashraf GM, Greig NH, Khan TA, Hassan I, Tabrez S, et al. (2014). Protein misfolding and aggregation in Alzheimer's disease and type 2 diabetes mellitus. CNS Neurol Disord Drug Targets 13: 1280-1293.

78. Khan NM, Ahmad A, Tiwari RK, Kamal MA, Mushtaq G, et al. (2014). Current challenges to overcome in the management of type 2 diabetes mellitus and associated neurological disorders. CNS Neurol Disord Drug Targets 13: 1440 1457.

79. Bass AJ, Lawrence MS, Brace LE, Ramos AH, Drier Y, et al. (2011) Genomic sequencing of colorectal adenocarcinomas identifies a recurrent VTI1ATCF7L2 fusion. Nat Genet 43: 964-968.

80. Frayling TM, Colhoun H, Florez JC (2008) A genetic link between type 2 diabetes and prostate cancer. Diabetologia 51: 1757-1760.

81. Banerji MA, Faridi N, Atluri R, Chaiken RL, Lebovitz HE (1999) Body composition, visceral fat, leptin, and insulin resistance in Asian Indian men. J Clin Endocrinol Metab 84: 137-144.

82. Chandalia M, Abate N, Garg A, Stray-Gundersen J, Grundy SM (1999) Relationship between generalized and upper body obesity to insulin resistance in Asian Indian men. J Clin Endocrinol Metab 84: 2329-2335.

83. Raji A, Seely EW, Arky RA, Simonson DC (2001) Body fat distribution and insulin resistance in healthy Asian Indians and Caucasians. $J$ Clin Endocrino Metab 86: 5366-5371.

84. Ramachandran A, Snehalatha C, Kapur A,Vijay V, Mohan V, et al. (2001) Diabetes Epidemiology Study Group inIndia (DESI). High prevalence of diabetes and impairedglucose tolerance in India: National Urban Diabetes Survey. Diabetologia 44: 1094-1101.

85. Mohan V, Deepa M, Deepa R, Shanthirani CS, Farooq S, et al. (2006) Secula trends in the prevalence of diabetes and glucose tolerance in urban South India-the Chennai Urban Rural Epidemiology Study (CURES-17). Diabetologia 49: $1175-1178$.

86. Singh S (2011) Genetics of Type 2 diabetes: A Review. Journal of Scientific Research, Banaras Hindu University 55: 35- 48.

87. Bodhini D, Radha V, Dhar M, Narayani N, Mohan V (2007) The rs 12255372 $(\mathrm{G} / \mathrm{T})$ polymorphism of the TCF7L2 gene is associated with type 2 diabetes in Asian Indians. Metabolism Clinical and Experiment 56: 1174-1178.

88. Chandak GR, Janipalli CS, Bhaskar S, Kulkarni SR, Mohankrishna P, et al 
(2007) Common variants in the TCF7L2 gene are strongly associated with type 2 diabetes mellitus in the Indian population. Diabetologia 50: 63-67.

89. Chauhan G, Spurgeon CJ, Tabassum R, Bhaskar S, Kulkarni SR, et al. (2010) Impact of common variants of PPARG, KCNJ1, TCF7L2, SLC30A8, HHEX CDKN2A, IGF2BP2, and CDKAL1 on the risk of type 2 diabetes in 5,164 Indians. Diabetes 59: 2068-2074.

90. Tabassum R, Chavali S, Dwivedi OP, Tandon N, Bharadwaj D (2008) Genetic variants of FOXA2: risk of type 2 diabetes and effect on metabolic traits in North Indians. J Hum Genet 53: 957-965.

91. Singh S, Prasad SB, Yadav SS, Agrawal NK, Narayan G (2012) Association of common variants of CDKN2A/2B rs10811661 (C/T) and WFS1 rs6446482 $(\mathrm{C} / \mathrm{G})$ with type 2 diabetes mellitus in Indian population of eastern Uttar Pradesh. J Diabetes Metab 3: 9

92. Ali S, Chopra R, Manvati S, Singh YP, Kaul N, et al. (2013) Replication of type 2 diabetes candidate genes variations in three geographically unrelated Indian population groups. PLoS One 8: e58881.

93. Janssens AC, Gwinn M, Khoury MJ, Subramonia-lyer S (2006) Does genetic testing really improve the prediction of future type 2 diabetes? PLoS Med 3 : e114.

94. Weedon MN, McCarthy MI, Hitman G, Walker M, Groves CJ, et al. (2006) Combining information from common type 2 diabetes risk polymorphisms mproves disease prediction. PLoS Med 3: e374.

95. Lyssenko V, Almgren P, Anevski D, Orho-Melander M, Sjögren M, et al. (2005) Genetic prediction of future type 2 diabetes. PLoS Med 2: e345.

96. Vaxillaire M, Veslot J, Dina C, Proença C, Cauchi S, et al. (2008) Impact of common type 2 diabetes risk polymorphisms in the DESIR prospective study. Diabetes 57: 244-254.

97. Cauchi S, Meyre D, Durand E, Proença C, Marre M, et al. (2008) Post genomewide association studies of novel genes associated with type 2 diabetes show gene-gene interaction and high predictive value. PLoS One 3: e2031.
98. Lyssenko V., Laakso M (2013) Genetic Screening for the Risk of Type 2 Diabetes. Worthless or valuable? Diabetes care $36: 120-126$

99. McCarthy MI1 (2010) Genomics, type 2 diabetes, and obesity. N Engl J Med 363: $2339-2350$

100. Morris AP, Voight BF, Teslovich TM, Ferreira T, Segrè AV, et al. (2012) Wellcome Trust Case Control Consortium; Meta-Analyses of Glucose and Insulinrelated traits Consortium (MAGIC) Investigators; Genetic Investigation of ANthropometric Traits (GIANT) Consortium; Asian Genetic Epidemiology Network-Type 2 Diabetes (AGEN-T2D) Consortium; South Asian Type 2 Diabetes (SAT2D) Consortium; DIAbetes Genetics Replication And Metaanalysis (DIAGRAM) Consortium. Large-scale association analysis provides insights into the genetic architecture and pathophysiology of type 2 diabetes. Nat Genet 44: 981-990.

101. Pascoe L, Tura A, Patel SK, Ibrahim IM, Ferrannini E, et al. (2007) Common variants of the novel type 2 diabetes genes CDKAL1 and HHEX/IDE are associated with decreased pancreatic beta-cell function. Diabetes 56: 3101 3104.

102. Staiger H, Machicao F, Stefan N, Tschritter O, Thamer C, et al. (2007) Polymorphisms within novel risk loci for type 2 diabetes determine beta-cell function. PLoS One 2: e832.

103. Staiger H, Stancakova A, Zilinskaite J, Vanttinen M, Hansen T, et al (2008) A candidate type 2 diabetes polymorphism near the HHEX locus affects acute glucose-stimulated insulin release in European populations: results from the EUGENE2 study. Diabetes 57: 514-517.

104. Talmud PJ, Hingorani AD, Cooper JA, Marmot MG, Brunner EJ, et al. (2010) Utility of genetic and non-genetic risk factors in prediction of type 2 diabetes: Whitehall II prospective cohort study. BMJ 340: b4838.

105. Maruthur NM, Gribble MO, Bennett WL, Bolen S, Wilson LM, et al. (2014) The pharmacogenetics of type 2 diabetes: a systematic review. Diabetes Care 37: 876-886. 